\title{
A discourse on the potential of crowdfunding and Islamic finance in the agricultural sector of East Java, Indonesia
}

\author{
Hassanudin Mohd Thas Thaker ${ }^{1 *}$, Ahmad Khaliq ${ }^{2}$, K Chandra Sakaran ${ }^{3}$, Mohamed Asmy Mohd \\ Thas Thaker ${ }^{4}$ \\ 1 Department of Economics and Finance, Sunway University, Petaling Jaya, Selangor Malaysia \\ 2 International Islamic University Malaysia, Gombak, Selangor, Malaysia \\ ${ }^{3}$ HELP University, Bukit Damansara, Kuala Lumpur, Malaysia \\ 4 International Islamic University Malaysia, Gombak, Selangor, Malaysia \\ *Corresponding author: hassanudint@sunway.edu.my
}

\section{Keywords:}

Agriculture, crowdfunding, Islamic finance, agricultural sector, East Java

\section{Article History}

Received: 03 December 2019

Accepted: 08 January 2020

Published: 22 January 2020

DOI:

10.20885/JEKI.vol6.iss1.art2

JEL:

A13, G32, H41, Q14, R11, Z12

\begin{abstract}
Literature evidence on the transformation transpires agriculture sector in East Java for the last 5 to 10 years. The contribution of the agricultural sector towards East Java gross domestic product (GDP) in 2008 recorded at $16.55 \%$, however, shrinks to $13.75 \%$ in 2015 . This statistic shows the regressed contribution of the agriculture sector in comparison to other economic sectors. One common view that linked to shrinking in credit composition is due to the lack of credit accessibility for the sector. Given that, this paper attempts to propose a viable financing model to develop the agricultural sector in East Java known as Integrated Agricultural Land Crowdfunding Model (IALCM) using Islamic financing instruments through a crowdfunding platform. This model is expected to offer farmers in East Java to meet their liquidity constraints and the Indonesian government to accelerate social entrepreneurship innovation with conceivable recommendations for the development of agricultural sector in East Java.
\end{abstract}

\section{Cite This:}

Thaker, H. M. T., Khaliq, A., Sakaran, K.C., Asmy, M., \& Thaker, M.T. (2020). A discourse on the potential of crowdfunding and Islamic finance in the agricultural sector of East Java, Indonesia. Jurnal Ekonomi dan Keuangan Islam, 6(1), 10-23. DOI: 10.20885/JEKI.vol6.iss1.art2

\section{Introduction}

The Java land of Indonesia resides at an estimated of 266.97 million population in the year 2018. This Java land alone populated by $56.7 \%$ of the whole of Indonesia's population. It consists of provinces namely Banten, Jakarta, Jawa Barat (West Java), Jawa Tengah (Central Java), Yogyakarta and Jawa Timur (East Java). Java's land area denotes almost 10\% of Indonesia's region. Near 57\% of Indonesia's general population living in Java provinces, resulting in a very high population density.

In relation to that, Central Bureau Statistics of Indonesia (2013) reported that agriculture sector has seen major contributor to Indonesian agriculture and it were among the core sector for East Java's household activities where number of agricultural business household in 2013 was 4.98 million households comprises of food crops, horticulture, plantation, husbandry, fishery and forestry. It has always been a vital source that unswervingly contributes to the national economy such as to the food supply, foreign currency earnings, provision of employment, and supply of raw material which profoundly contribute to the gross domestic product (GDP) of a country. Especially for a nation alike Indonesia which is profusely arable according to their geographical 
location, agriculture sector there found to significantly contribute to their national development. The year 2010 to 2016 shown abundant provision of agriculture to the Indonesian economy. The World Bank data in Figure 1 below depicts that around 13.86 percent with a minimum of 13.67 percent in 2012 and a maximum of 14.31 percent in 2010 were recorded as the contribution rate for the agriculture sector alone to the nation's GDP. These include the forestry, hunting and fishing, cultivation of crops and also livestock production.

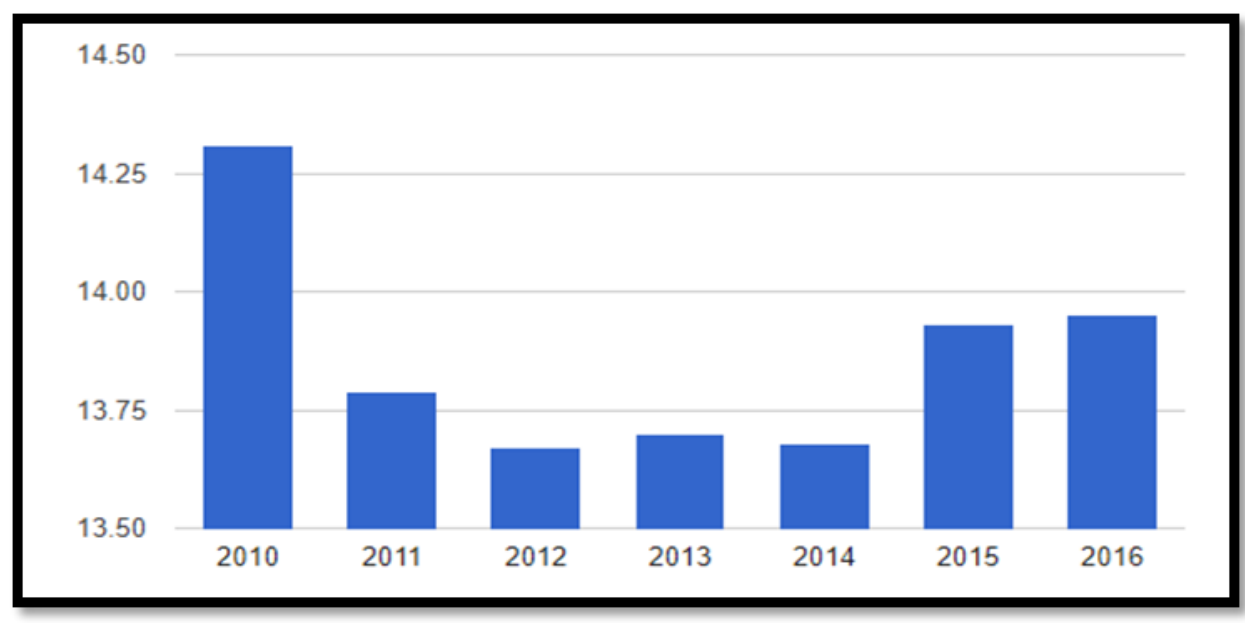

Figure 1. Indonesia's GDP Share of Agriculture Source: The World Bank (2017)

Apparently, together with the surge in their GDP contribution, the rise in the allocation of agricultural land also had been noticed for the same year with the average value of 31.24 percent. This infers that great support is set by the government as an initiative to sustain this sector. The support of the ruling government is also crucial as each sector is differently affected by changes in agricultural production and prices (Zyl, et al., 1988).

To provide sustainable financial aid for the agriculture sector continues to be a challenge despite billions of funds spent on subsidies and strengthen the financial need of the sector (Meyer, 2013). Rice cultivation has always been the key commodity for Indonesian agriculture ever since 1968. Even though with forecast calamities for the sector due to climate change such as ElNino, rice production was maintained encouraging as the government was providing farmers with sufficient fertilizer, good quality seeds, and pesticides during the year 1984. Other vital agriculture products are cassava, tea plantation, rubber and palm oil farming (Riethmuller, 1999).

Unfortunately, the study realized that the national food security outline as the rice selfsufficiency remains a vital concern for the government until recently. The policy layout was not prosperous when at the same time lesser heed was taken on the investment of land and water resources development during 1984. Issues with regards to land development include the transformation of productive agriculture areas into critical land; having a marginal land that possess little or no potential to cultivate and often poor undesirable soil characteristics; sleeping land or neglected land that are low land productivity and failures of harvest due to pest outbreaks and floods; transform of paddy rice land to other non-agriculture land which results to unavoidable demand for appropriate land; land fragmentation, when a number of lands are farmed in division of smaller production unit over successive generation of farmers; inappropriate infrastructure of irrigation. On the other hand, issues with the water resources include rising demand for water; lack of upstream land management; erosion related degradation; population growth; inefficient of water irrigation; extreme climate change; and over-pumping of groundwater (Suprapto, 2002).

In the year 1993, the self-sufficiency rice aim could not last longer point out by the growth of rice import. Later then, certain national actions were appreciated which results in a 
surge in the quality of crop intensification, expansion of planting area, improved agriculture infrastructure and facilities in the year 2000 (Suprapto, 2002). On the same note, even though the sector receives appropriate courtesy, with the anticipation of a two percent population increase annually, the significant budget must be a quest and assign.

In fact, during the Asian financial crisis in 1997 and 1998, Indonesia had severely obstructed henceforth results to collapse of confidence in the finance and banking system follows with the rapid fall in exchange rates in the Southeast Asian countries. The social effects of the crisis depict that wage-workers in developing countries can return to their villages if they lose their city jobs, which were abundantly practised when the wage sector workforce was very small. Inopportunely, that was not the case with the introduction of new farming techniques and technology where agricultural productivity employs fewer people than traditional methods. The local government acknowledges the challenges faced by rural farmers such as low capital ownership and less accessibility of financing. As a consequence, farmers commonly seek for external financial assistance, which could be attained from two categories either through formal institutions like banks and government agencies, or other option through the informal means by acquiring from the neighbours, friends, relatives or micro-finance institutions. Despite with high cost of financing, farmers usually opt for the funding through the informal institutions as they are more accessible, demand no collateral with trust and do not require long procedures (Asnawi, et al., 2018). Different from some areas in Indonesia including South Sulawesi, Sirajuddin, et al. (2015) found that they are quite developed in a profit-sharing known as Muzara'ab where the landowner and the other party who cultivate the land enters into an agreement with the share of harvest by half, one third, or by mutual consent prior agreed.

Nevertheless, the issue and challenge on how to secure financial resources for the agricultural endeavour commonly remain immense queries. Thus, to overcome this issue, the use of a crowdfunding platform can be the best solution.

The development of local production capacity needs to be held up by food security institutions that could guarantee the sufficiency of food requisite at the household level, inclusive with the quantity measures, quality of the productions, the security, and together at the affordable cost for various kind of local food resources. Later, these measurements could realize a competitive nation by making efficiency, modernization, and further increase agricultural value so it could compete in the local and international markets (Harjanto, 2011). Having adequate financial resources and its consumption on research and development, the agricultural sector has the potential to grow further and optimally productive in the future. Positive forecasts of this sector are attainable for precision agriculture technology where each and every plant can be virtually monitored by the integration of technologies comprises artificial intelligence, big database, sensors for fertilization and irrigation measures for the crops fields.

In addition, with the use of precision agricultural technology that has been widely implemented in several countries in the world, it also aims to reduce the environmental impact of agricultural endeavour at the same time increase productivity, optimize input and output of agriculture production plus it also contributed maintain the soil quality.

Referring to the literature discussed, this paper claims three main contributions. Firstly, this study offers a new method of financing to enhance the development of agricultural land and activities related to agricultural using Islamic finance instruments. With this mode of crowdfunding financing, the reliance on financial institutions and government to access financial support will become less. This financing pattern is found exceptionally accommodating to the local culture that progresses in countryside communities of East Java. Secondly, the suggestion given in this study is expected to reduce government expenditure related to agriculture. Probably, in the future, the government of Indonesia can apply this type of financing to other economic sectors as well. Finally, the outcome of this study is expected to enrich the literature available in the context of the crowdfunding platform. The general research gaps found in the existing 
literature are (i) the existing model is mainly focus on conventional financing which can further burden the farmers without exploring the innovation in the existing model, (ii) literature in the context of agricultural financing are limited especially in Indonesia where the focus of research are more zoom into general problem instead financing problem and (iii) existing studies also did not postulate any alternative ways of assists farmers finally. We believe that Islamic finance and crowdfunding concept can play an important in the perspective.

In the last years, the concepts of crowdfunding have gained acceptance as the alternate source of financing for innumerable ventures globally. Crowdfunding is an initiative to fund projects across industries such as journalism, technology, music, film, and others, through crowdsourced. For instance, projects exhibit on the Kickstarter which based in the United States is known as one of the largest platforms for crowdfunding. In fact, one of the three nominated for Oscar award movie projects funded by crowd investors won the award in Oscar 2013 for the short documentary category (Lu, et al., 2014).

Unlike the conventional investor in venture capital firms where the enterprises receive a small number of major investments, in crowdfunding, the enterprise receives supports through a large number of small contributions from investors. Therefore, crowdfunding presents a mixture of entrepreneurship and social network participation. In addition, the investor in the crowdfunding projects can keep track of their campaign and obtain useful insight in real-time which ordinarily shared through crowdfunding websites or even in social media.

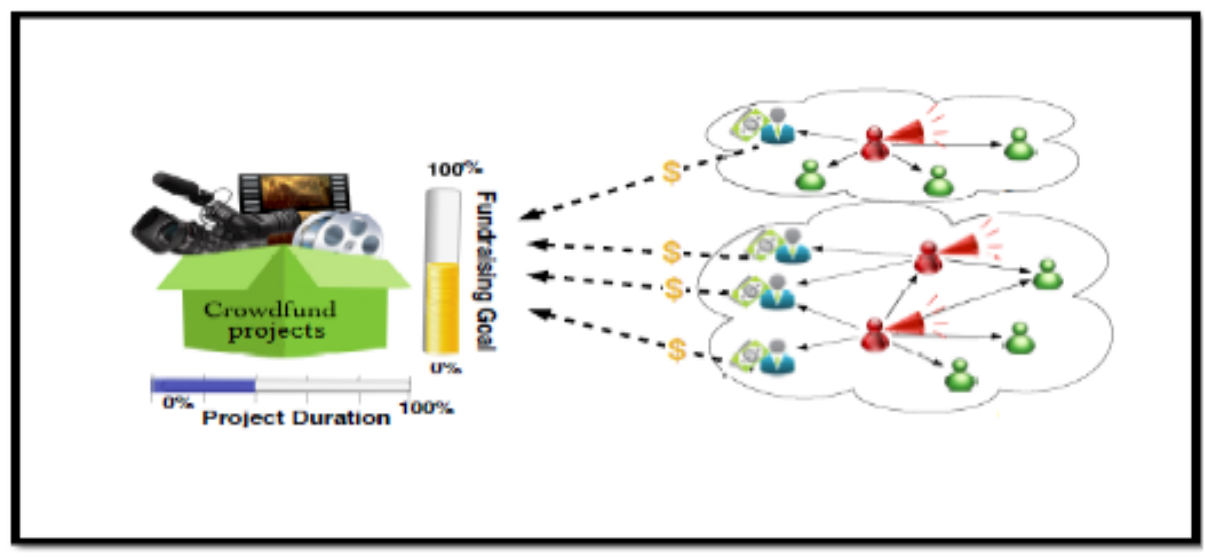

Figure 2. Crowdfunding Process

Source: Lu, et al. (2014)

The figure above illustrates the example of a crowdfunding process where the red persons act as promoters of the projects, the person in blue are the backers, while the green is the potential target investors. Generally, the investor has the liberty to choose projects according to their priority to contribute. If the fundraising goal is achieved, the funds are awarded to the proposer or the crowdfunding project specified (Mollick, 2013). Initially, the crowdfunding has dominantly cast for funding artists from different sectors (Agrawal, et al., 2013). Subsequently, other artistic and creative areas such as film and journalism adopted the idea. The crowdfunding platform was seen as the way to reduce the funding gap in the early stages of new ventures, then only venture capitalist and banks would be available in later development phrases of startups. Diverse areas of the globe have known to have a different word of reference for the crowdfunding activities. Another term for crowdfunding also known as social-lending (Hulme \& Wright, 2006), peer-to-peer (Freedman \& Jin, 2014) and crowd-investing in Germany) which is to distinguish the equity-based form of crowdfunding (Moritz \& Block, 2016).

Generally, four crowdfunding models are found with different in analysis among countries which is based on equity, lending, donation, and reward (Brüntje \& Gajda, 2016). Kuppuswamy \& Bayus (2018) research demonstrated that crowdfunding could be categorized 
such the Sellaband; where the investors anticipate an interest in the profit-sharing oriented venture, Prosper; crowdlending activities in which the investor expects the original principal is repaid along with some interest, JustGiving; the funder voluntarily donate their money with no expectation of any tangible reward, and Kickstarter; where project backers receive nonfinancial rewards for their contributions (Agrawal, et al., 2015; Zhang, et al., 2012; Smith, et al., 2014; Mollick, 2014). Further explanation on categories of crowdfunding (extracted from Thaker \& Thaker, 2018) are given below:

1. Donation Crowdfunding. Donation crowdfunding is where the collection of funds takes place for the purpose such as social, artistic, philanthropic and others. Basically, this type of crowdfunding is not based on any exchangeable of tangible value. For example, in the United States, Kickstarter, Indiegogo, etc. are among the platforms supporting donation-based crowdfunding.

2. Reward Crowdfunding. Reward crowdfunding is the collection of funds, where the investors or donors receive some tangible reward (such as a membership rewards scheme) as a token of appreciation. Most of the websites which support donation crowdfunding are also managing reward-based crowdfunding, such as Kickstarter, Rockethub, Indiegogo, etc.

3. Lending Crowdfunding, Lending crowdfunding is a platform that matches lenders or investors with borrowers or issuers to provide loans with a lower interest rate, which is set by the platform. There are some platforms arrange loans between individuals, while other platforms collect funds and then lent to small and medium enterprises. Some of the leading examples from the US are Lending Club, Prosper, etc. and from the UK are Zopa, Funding Circle, etc. Some of the platforms charge a fee based on the loan.

4. Equity-Based Crowdfunding. Equity-based crowdfunding refers to the fund raised through online by a business, particularly early-stage funding, by offering equity interests in the business to investors. Businesses that are looking to raise capital through this mode typically advertise online through a crowdfunding platform website, which serves as an intermediary between investors and start-up companies. In the United Kingdom two platforms namely Crowdcube and Seedrs have dominated the narrative for investment crowdfunding from the equity side.

On the other note, Gleasure \& Feller (2016) on study of crowdfunding patterns of behaviour classified dominant categories of crowdfunding endeavours known as crowdlending (investing in return for repayment at some agreed-upon rate of interest), crowd equity (investing in return for equity/securities), crowd patronage (investing in return for benefits from a proposed product/service) and crowd charity (investing without expectation of any financial or return in any form). Conventionally speaking, equity-based crowdfunding such as crowd equity is suitable for agriculture financing. The figure below depicts the categories of crowdfunding system.

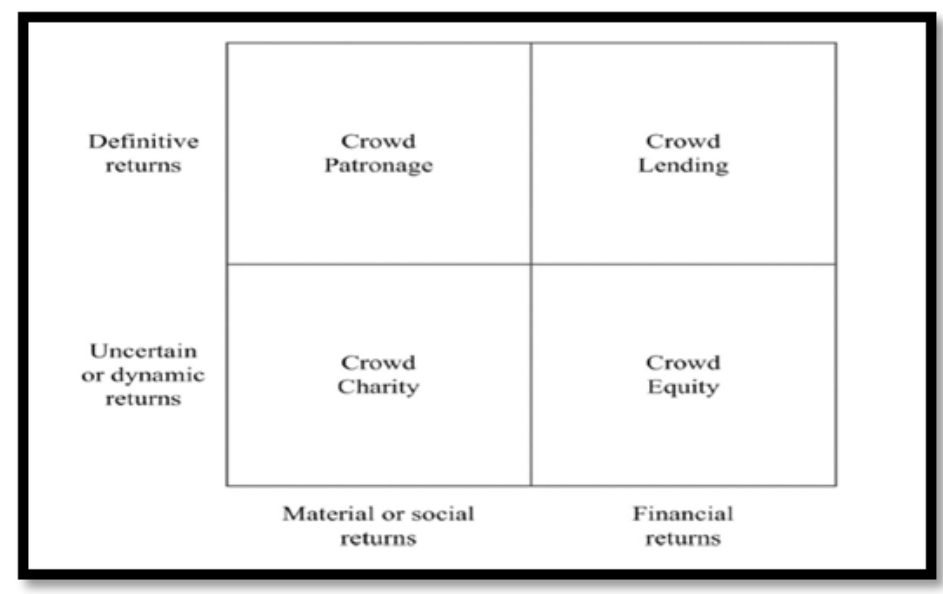

Figure 3. Categories of Crowdfunding System Source: Gleasure \& Feller, (2016) 
The crowdfunding platforms eventually are seen to advantage the funding mechanism including; minimal cost and effort involved, multiple transactions could be pooled together to fund less risky projects, and it also could mitigate the asymmetry information between funders and fund seekers.

The development of crowdfunding discussion was mainly focused on legal issues. Later, restrictions on the concept dominated the literature vastly on the legislative concern (Belleflamme, et al., 2010). Subsequently, a number of scientific contributions began to emerge on the notion of descriptive exploration and concept-based or explanatory approach, frequently with case studies from a particular national context (Ingram, et al., 2014).

Entrepreneurs opted for crowdfunding concept found to get motivated due to few reason such as the collection of funds itself, to attain the public attention, receive feedbacks for their goods and services, self-affirmation, replication of success stories and increase awareness of the goods and services provided (Belleflamme, et al., 2013; Gerber, et al., 2012). Kuppuswamy \& Bayus (2018) claimed that to date, mainstream empirical research on crowdfunding focuses to identify the project and entrepreneur characteristics associated with successful funding outcomes. For instance, number of research shows that the funding completion is positively associated to project quality signals such as preparedness (Mollick, 2014), chronical in project depiction (Herzenstein, et al., 2011); (Allison, et al., 2015), individual quality signals such gender, race, personal characteristics (Gorbatai \& Nelson, 2015); (Marom, et al., 2016), creditworthiness (Zhang, et al., 2012), internal capital accumulated from supporting other projects (Colombo, et al., 2015), social networks, and the geographic distance between entrepreneur and their contributors (Agrawal, et al., 2015). Nevertheless, studies by Gleasure \& Feller (2016) identifies that two fundamentally novel and under-researched variables related to funding behaviors are the erosion of organizations' financial boundaries and paying to participate variables.

Due to overwhelming and promising growth in crowdfunding endeavour, many countries such as Malaysia, Indonesia, UK, the US, Australia, China, Singapore, and others have eventually taken steps to acknowledge and amend their regulatory system to accommodate the operation of crowdfunding. Particularly the crowdfunding operation with the expectation of financial returns for crowdlending and crowd equity (Abdullah, 2016). In Malaysia, the equity crowdfunding gains its regulatory acknowledgement when SCM issued a public consultation paper to propose the regulatory framework for equity crowdfunding operation. Later in February 2015, Guidelines on Regulation of Markets under Section 34 of the Capital Markets and Services Act 2007 was released to provide governance arrangements for the operation of such platforms (Abdullah, 2016). Singapore advanced further to root their crowdfunding activities on the Shariah principle especially for the equity-based platforms, named Islamic crowdfunding.

The philosophy of Islamic banking relies on two main principles: (i) equivalent sharing of profit and loss and (ii) prohibition of Riba (payment of interest), gambling (Maysir) and speculative profit (element of Gharar). The rule of Islamic which is known as Shariah law used widely in Islamic banking practices covering ranges of Islamic financial products. This rule specifically based on Qur'an and the Sunna.

The financial institutions providing a great deal of flexibility, creativity, and choice with the offering of various products using various Islamic financial concepts such as Ijarah (leasing), Mudharabah (profit sharing), Musharakah (partnership), Murabahab (price deferred sale contract), Salam (object deferred sale contract) and Istisna (object and price sale contract) (IOSCO, 2004). This system has clearly provided a new dimension of the current economics models and mainly focuses on real economics activities (Fazlan \& Mohammad, 2007). The key concepts of the Islamic finance system zoom into sharing of risk, equity and all stakeholders.

The distribution aspect as the main requirement in the Islamic banking system indicates that the upshot of a project, whether it is profitable or otherwise, will be shared in a proper and equitable manner (Dusuki \& Abdullah, 2007). The main idea of the existence of Islamic 
philosophy is to obtain fair and justice distribution fo wealth. According to Erol et al. (1990), the fair and justice distribution to all parties who are involved in the real economic transaction and to promote equivalent welfare for the entire society. One of the most current financial instruments that promoting equivalent welfare in assisting the entrepreneur for financial support is called as "Islamic crowdfunding".

The objective of crowdfunding is to lessen the financial difficulty to a particular group of people or entrepreneurs who need financial assistance. This mechanism is a noble exercise and reflects the principles of Muamalat (facilitating transactions) in Islam. The real essence of Muamalat in Islamic commercial law promotes dealings between two or more parties to buy or, and sell products or services with reference to Shariah principles and emphasizes on being just and fair to each other in the deals made. Nevertheless, there are three main differences between conventional and Islamic crowdfunding namely (i) Shariah-compliant crowdfunding invests in halal socially responsible projects/products, (ii) shares the risks of the investment, and (iii) the absence of interest or Riba (Marzban, et al., 2014).

This paper is an attempt to present a conceptual framework of an alternative model such as the Integrated Agricultural Land Crowdfunding Model (IALCM). The present paper is purely qualitative in nature, using content analysis. Before proposing an appropriate model, this paper effectively analyses various relevant literature from academic research journals, websites, and electronic databases. In addition to the journal paper, the present study also refers to working paper, government report and websites as they provide very useful information to the researchers or practitioners. But, the refereed academic research journals epitomize the premier level of research in this paper to develop the model.

\section{Research Method}

This conceptual paper combines previous research work and explains the financing opportunities to solve financial constraints facing farmers in East Java, Indonesia. The focus is to make sure that all the farmers have enough funding for agricultural-related activities. As mentioned in the introduction part, smallholder farmers often struggle to raise sufficient capital for farming purposes, as the banking system requirement is difficult for them to access. This is due to most banks requiring collateral and having a lengthy and complicated application process and unfavourable interest rate. Therefore, many farmers get into insolvency after borrowing from loan sharks or other middlemen who take advantage of their plight with high-interest rate loans. Through this kind of financing arrangement as this study is proposed, we believe that farmers in East Java would be able to develop their agriculture land which includes raising livestock, growing fruit, and vegetables or trading commodities. Since the literature on agricultural land and crowdfunding is limited in the context of Indonesia, we have chosen only the relevant studies discussed the actual problem in agricultural lands and general review of literature about the crowdfunding platform. Most of the literature is taken from newspaper and refereed journal articles and reviewed critically in developing an alternative model.

\section{Results and Discussion}

There are many strategies and policies have been implemented to overcome the issue of undeveloped agricultural land. Unfortunately, not all strategies have been implemented resulting in the best outcome. Some are successful and some are fails or even dragged for many years without any implementation or improvement. Out of the many issues pertaining to agricultural land, one common issue that we come across is that financing problem. Most of the activities related to agriculture in Indonesia are financed by banks and the requirements to get financing have become more rigorous. Furthermore, the role of the Indonesia government like the Ministry 
of Agricultural and Rural Development (MARD) and The Ministry of Environment and Forestry are also undeniable.

The support from these government agencies is valuable and supportive with many policies and strategies agricultural improvisation and development. One of the initiatives was the government of Indonesia's 2015-2019 National Medium-Term Development Plan (RPJMN). Under the plan, there are plenty of ideas and plan to be initiated such as the development of farm roads, increased adoption of environmentally friendly technologies for food crops, Water security, improved land use planning and management, increased water storage and make use all the abandoned land for agriculture purpose. During the CEO Talks Series at the beginning of the year, Chairman of Himpunan Kerukunan Tani Indonesia (HKTI) mentioned that there is great potential to succeed in the agricultural industry and farmers need to find innovative ways handling the land and activities related agriculture to achieve greater success in this field.

However, the issue of land such farmers have too many large and small lands and do not how to manage all those lands. Furthermore, the accessibility towards financing also adds to the problems where some lands are just abandoned or operating on a small scale due to financial problems. Since, today the business moving towards globalization and digital era, farmers need to find a better source of financing alternatives to overcome this problem. Obviously, there is much reason to hurdle the development of the agricultural industry in East Java apart from the financial issue and in the end, in searching for root causes of less development in the agriculture industry, it is caused by the financial problem. Therefore, there is a need alternative mode of financing by considering this issue. Thus, an Integrated Agricultural Land Crowdfunding Model (IALCM) is proposed to address this issue. An interesting aspect of this model is that we have incorporated the crowdfunding platform without having financial intermediaries. With this model, the IALCM aims to tackle the main challenge related to agricultural land in an integrated approach. The conceptual framework of the proposed IALCM model is illustrated in the figure below.

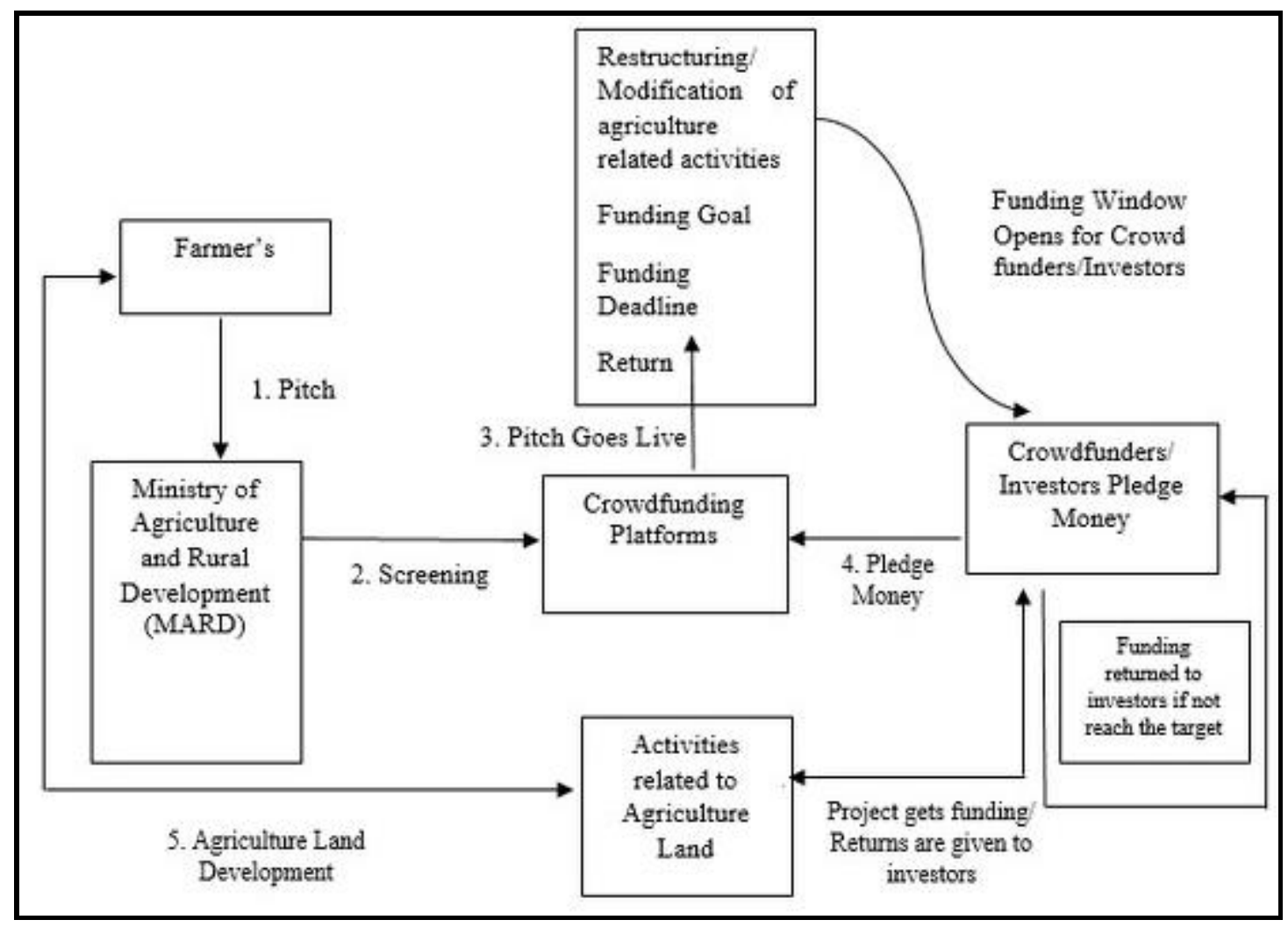

Figure 4. Integrated Agricultural Land Crowdfunding Model (IALCM) Sources: Author's Illustration 
Note: This figure shows the conceptual framework of IALCM developed to help the development of agricultural land in East Java, Indonesia.

\section{Operation of IALCM}

1. Basically, there is a need to raise the funding from crowd funders or investors to develop agricultural land or activities related to agriculture. Framer's design restructuring plans related to agriculture land and activities related to agriculture. Farmers' will submit their plan to authority. In this case, an example of authority would be the Ministry of Agriculture and Rural Development (MARD). The ministry will choose and screening the best, reliable and well-planned idea (arrow 1).

2. Once finalized the best budget with proper plan related to agriculture activities MARD will upload and submits the potential of particular activities related to agriculture land proposal into the platform which is known as Web-Based Platform and Social Network or outsourcing from external parties. The idea or proposal has to be funded within a predefined time frame. The projects have to be funded within a predefined time frame. In this model, this research proposed to use Murabahah-based crowdfunding, Sadaqahbased crowdfunding, and Hibah-based crowdfunding. Only interested investors are encouraged to take part in this financing scheme. Once the agriculture activities are completed, then when the finish goods from the agriculture are sold to the buyers (proceeds from the selling of finished goods will be distributed based on prearrangements (based on negotiation at an early stage) of investors). This matter will be discussed before proceeding to raised funds using the platform. (Arrow 2 and 3).

3. Crowd-funders or investors select the best agriculture activities as shown in the system that they want to support. Crowd-funders or investors browse the web to search requests and finally choose the selected ideas that they are willing to provide the fund or capital. (Arrow 4).

4. Crowd-funders or investors transfer/send funds through payment gateways, MARD or NGO can have its own payment gateways through collaboration with existing financial institutions or crowdfunding platforms. Once the target amount of funds from crowd funders is reached, the system will update the status of agriculture plans and keep track of received funds until it is ready to be distributed. If the fund is not reached to its target, the fund will be returned to the crowd funders or investors (arrow 4)

5. If the fund is successfully raised, the system distributes the fund to the developer via MARD and notifies them to get ready to initiate, managing and supervising the plan they proposed earlier (arrow 5).

6. MARD must track the progress regularly and updates the progress into the system until the particular plans completed. This will ensure transparency between them and the crowd funders. The system communicates with MARD as for control and audit purposes through a simple communication media such as short message services (SMS) or WhatsApp web (arrow 5)

7. Finally, within the specified time framework of the plan, farmers via MARD need to provide a return to the crowd funders or investors as mentioned in step number 2 and the remaining kept by themselves.

From the Integrated Agricultural Land Crowdfunding Model (IALCM) developed, it can be noticed that there is potential in developing agriculture land and farmers can explore more activities related to agriculture business with full utilization of economic resources and achieve better economies of scales. This model also helps in minimizing the dependency towards financial institutions in getting funds to support the idea or plan related to land. By considering 
broader perspectives, this suggested model could bring a substantial impact to the farmers, government and society. The significance of this model are explained below:

This model incorporates the crowdfunding platform in raising fund for agriculture land and activities related to the agricultural industry, thus it may benefit specifically to the farmers. Farmers will get the fund required to harvest and developing land on time as the time is given not only for the raised fund but also to complete the responsibility given on time. The process is transparent in the sense that the farmers need to update to the MARD about the development. This model is also suitable for farmers involved in small as well as large agricultural land. As mentioned earlier, this model able to reduce the dependency level towards financial institutions.

This model obviously anticipated to bring benefits to the government and society. As this model emphasizes the financing issues, it creates an environment of innovation and diversification of economic activity. It also helps in stimulating the performance of agriculture industry in Indonesia. As this model suitable for large and small agricultural land, it probably increases the utilization of economic resources and achieves a better economy of scale. Furthermore, since this model uses crowdfunding as a platform to raise funds, it is expected that corporate and investors can diversify and meet their portfolio investment objectives. It also allows us to perform social entrepreneurship contributions. Moreover, with this proposed model, we can expect that government expenditure, especially towards budgeting fund for financing agricultural industry, will become less. Case in the hold, it also helps in creating job opportunities in the market, subsequently increases the standard of living and boost economic performance.

There are four challenges identified in this paper to undercover the possible challenges for crowdfunding in the agricultural industry in East Java, Indonesia. Below shows the description of the challenges:

1. Awareness. The level of awareness about the crowdfunding perhaps might be low among the farmers as they have not quite yet adapted to the current technology development. Most of them have less knowledge about the operational side of crowdfunding and the purpose of this method of financing. As far as farmers are a concern, to get financing, they will always refer to banks. This could be one of the reasons why the crowdfunding is least popular among East Java Farmers. Thus, it is very important to create awareness with regard to crowdfunding and how does it work. Crowdfunding using an electronic platform to raise cash, therefore farmers need to be educated about this electronic platform. The basic background of the financial market and the digital environment needs to equip by the farmers who plan to use crowdfunding. This is because farmers need to come out with an appropriate video that related to their agricultural activity and this video will be uploaded in the crowdfunding platform. The platform had to persuade investors that the funding agriculture projects are solid and will result in good returns.

2. Government role. As of now, there is no appropriate rules and regulation related to crowdfunding financing in Indonesia. Due to this, some investors might not be very much interested to invest in any project due to high risk and unclear terms and conditions. Thus, the regulatory framework has to restructure and harmonized. Furthermore, private sector investment in the rural area has to be improved to attract other private companies to invest in the rural area especially related to agricultural. Most of the development is focused on urban instead of rural areas. This has to be changed. A good partnership between government and the private sector in building agricultural land would be fascinating to grow this industry.

3. Crowdfunding Investors. The next challenge that haunting the potential of crowdfunding is to look for an investor who wants to invest in the related project. It is noted that investors will view the project video uploaded on the platform and they will start to invest in it. This is a very common matter through this arrangement and it also helps in the build-up 
of social entrepreneurship and social responsibility towards the entrepreneur. Looking at this context, there must be some incentive available to investors who invest in the project from the government. The incentive can be in the form of a tax shield or tax-deductible at the end of the year for those who have invested in the project. Later, more investors will try to invest in the project via crowdfunding due to this benefit.

4. Pioneering stage. This mode of financing is still at a pioneering stage in the context of Indonesia. Only a few investors or farmers know about this and not well developed. To create market confidence about crowdfunding, perhaps the MARD collaborate with the countries who have successfully implemented the crowdfunding like the United States and the United Kingdom or emerging market like Malaysia and many others. Learning from other countries would help in enhancing the structure, operation and information transparency involving crowdfunding. Furthermore, to reach rural communities about the benefit of crowdfunding, perhaps a forum for social dialogue and policy debates need to frequently carry on. Indirectly, this will also contribute to creating awareness about crowdfunding. With this arrangement, we can expect this financing mode would experience an expansion stage and widely held especially among farmers.

\section{Conclusion}

The study intends to propose a model or framework in overcoming the issue of financing related to the agricultural sector in East Java, Indonesia. Obviously, there are many issues haunting the progress of agricultural sector apart from a financial problem, this model specifically dealt with the financial problem facing by farmers. As mentioned in the literature, the issue of financial problem found to be one of the effects of lands are not well managed by farmers for agricultural purpose. So, this is a clear waste of economic resources and there is a need for a solution. Thus, to solve this issue, the current study proposes a solution using the model called the "Integrated Agricultural Land Crowdfunding Model (IALCM)".

This study claims that this model can support the development of agricultural land in East Java. There are only two limitations in this study where this study is a conceptual paper. It is just a discourse of the alternative model in mitigating the issue of agriculture land in East Java. Therefore, in the future, to see the effectiveness of this model, perhaps qualitative research is needed to get an opinion from the industry experts. Incorporating theories such as Theory of Reasoned Action (TRA) (Fishbein \& Ajzen (1975), Technology Acceptance Model (Davis, 1989) and Theory of Planned Behaviour (TPB) (Ajzen, 1991) can be very useful in this regard. Secondly, this model is just a framework to mitigate the financial problem facing by the farmers. We did not look at the economic implications of this model. The upcoming research perhaps can look at this field of research.

\section{References}

Abdullah, A. (2016). Crowdfunding as an emerging fundraising tool: with special reference to the Malaysian regulatory framework. Islam and Civilisational Renewal, (1), 98-119.

Agrawal, A., Catalini, C., \& Goldfarb, A. (2013). Some simple economics of crowdfunding. National Bureau of Economic Research (NBER) Working Paper No. w19133.

Agrawal, A., Catalini, C., \& Goldfarb, A. (2015). Crowdfunding: geography, social networks, and the timing of investment decisions. Journal of Economics and Management Strategy, 24(2), 253274. DOI: $\underline{10.1111 / \text { jems.12093 }}$

Ajzen, I. (1991). The theory of planned behavior. Organizational Behavior and Human Decision Processes, 50(2), 179-211. DOI: 10.1016/0749-5978(91)90020-T 
Allison, T. H., Davis, B. C., Short, J. C., \& Webb., J. W. (2015). Crowdfunding in a prosocial microlending environment: examining the role of intrinsic versus extrinsic cues. Entrepreneurship Theory and Practice, 39(1), 53-73. DOI: 10.1111/etap.12108

Asnawi, A., A.A. Amrawaty, \& Nirwana. 2018. Mukhabarah as sharia financing model in beef cattle farm entreprise. IOP Conf. Series: Earth and Environmental Science.

Belleflamme, P., Lambert, T., \& Schwienbacher, A. (2010). Crowdfunding: an industrial organization perspective. Workshop on Digital Business Models: Understanding Strategies, Held in Paris in June 2010.

Belleflamme, P., Lambert, T., \& Schwienbacher, A. (2013). Crowdfunding: tapping the right crowd. Journal of Business Venturing, 29(5), 585-609. DOI: $10.2139 /$ ssrn.1578175

Brüntje, D., \& Gajda, O. (2016). Crowdfunding in Europe, state of the art in theory and practice. Switzerland: Springer International Publishing.

Colombo, M. G., Franzoni, C., \& Rossi-Lamastra, C. (2015). Internal social capital and the attraction of early contributions in crowdfunding projects. Entrepreneurship Theory and Practice, 39(1), 75-100. DOI: $\underline{10.1111 / \text { etap.12118 }}$

Davis, F. D. (1989). Perceived usefulness, perceived ease of use, and user acceptance of information technology, MIS Quarterly, 13(1), 983-1003. DOI: 10.2307/249008

Dusuki, A. W., \& Abdullah, N. I. (2007). Why do Malaysian customers patronize Islamic banks? International Journal of Bank Marketing, 25(3), 142-160. DOI: $\underline{10.1108 / 02652320710739850}$

Erol, C., Kaynak, E. \& El-Bdour, R. (1990). Conventional and Islamic banks: patronage behavior of Jordanian customers, International Journal of Bank Marketing, 8(4), 25-35. DOI: $\underline{10.1108 / 02652329010004231}$

Fazlan, S., \& Mohammad, A. (2007). The efficiency of Islamic banks: empirical evidence from the MENA and Asian countries Islamic banking sectors. Paper presented at the Fifth International Islamic Finance Conference, 3-4 ${ }^{\text {th }}$ September, Kuala Lumpur.

Fishbein, M., \& Ajzen, I. (1975). Belief, attitude, intention and behaviour: an introduction to theory and research. Penn State University Press, US.

Freedman, S., \& Jin, G. (2014). The signaling value of online social networks: lessons from peerto-peer lending. National Bureau of Economic Research (NBER) Working Paper No. $19820,48-70$.

Gerber, E., Hui, J., \& Kuo, P. (2012). Crowdfunding: why people are motivated to post and fund projects on crowdfunding platforms. in computer-supported cooperative work (CSCW) Workshop, 2012.

Gleasure, R., \& Feller, J. (2016). Emerging technologies and the democratisation of financial services: A meta triangulation of crowdfunding research. Information and Organization, 26 (4), 101-115. DOI: $10.1016 /$ j.infoandorg.2016.09.001

Gorbatai, A. D., \& Nelson, L. (2015). Gender and the language of crowdfunding. Academy of Management Proceedings 1.

Harjanto, J.T. (2011). Precision agriculture toward sustainable food sovereignty. Badan Penyuluban dan Pengembangan Sumber Daya Manusia Pertanian (BPPSDMP), Ministry of Agriculture, Rep. of Indonesia. 
Herzenstein, M., Sonenshein, S., \& Dholakia, U. M. (2011). Tell me a good story and i may lend you money: the role of narratives in peer-to-peer lending decisions. Journal of Marketing Research, 48(2), 138-149. DOI:10.1509/jmkr.48.SPL.S138

Hulme, M., \& Wright, C. (2006). Internet-based social lending: Past, present and future. Social Futures Observatory.

Ingram, C., Teigland, R., \& Vaast, E. (2014). Solving the puzzle of crowdfunding: where technology affordances and institutional entrepreneurship collide. In System Sciences (HICSS), 2014 47th Hawaii International Conference On, IEEE, 4556-4567.

International Organization of Securities Commissions (IOSCO). (2004). Islamic Capital Market Fact-Finding Report, July 2004, p10 available at www.iasplus.com/resource/ioscoislamiccapitalmarkets.pdf (Accessed on 22 Feb 2018).

Kuppuswamy, V., \& Bayus, B. L. (2018). Crowdfunding creative ideas: the dynamics of project backers. In H. L. Cumming D., The Economics of Crowdfunding. (pp. 151-182). Cham: Palgrave Macmillan.

Lu, C.-T., Xie, S., Kong, X., \& Yu, P. S. (2014). Inferring the impacts of social media on crowdfunding. Proceeding WSDM '14 Proceedings of the 7th ACM international conference on Web search and data mining, 573-582. DOI: $10.1145 / 2556195.2556251$

Marom, D., Robb, A., \& Sade, O. (2016). Gender dynamics in crowdfunding (Kickstarter): evidence on entrepreneurs, investors, deals and taste-based discrimination. Social Science Research Network.

Marzban, S., Asutay, M., \& Boseli, A. (2014). Shariah--compliant crowdfunding: An efficient framework for entrepreneurship development in Islamic Countries. Paper presented at the Harvard Islamic Finance Forum, Boston, USA.

Meyer, R.L. (2013). Microcredit and agriculture: challenges, successes and prospects. In Microfinance in Developing Countries: Issues, Policies and Performance Evaluation, by Jean-Pierre Gueyie, Ronny Manos and Jacob Yaron, 199-226. London: Palgrave Macmillan, a division of Macmillan Publishers Limited. DOI: 10.1057/9781137301925 10

Mollick, E. R. (2013). The dynamics of crowdfunding: determinants of success and failure. Social Science Research Network, Electronic Journal, 29(1). DOI:10.2139/ssrn.2088298

Mollick, E. R. (2014). The dynamics of crowdfunding: an exploratory study. Journal of Business Venturing, 29(2), 1-16. DOI: 10.1016/j.jbusvent.2013.06.005

Moritz, A., \& Block, J. (2016). Crowdfunding: a literature review and research directions. In D. Brüntje, \& O. Gajda, Crowdfunding in Europe, State of the Art in Theory and Practice (25-53). Switzerland: Springer International Publishing.

Riethmuller, P. (1999). The Indonesian feed and livestock sector. a statistical overview. In Livestock Industries of Indonesia Prior to the Asian Financial Crisis, by Food and Agriculture Organization of the United Nations (Regional Office for Asia and the Pacific), 107-198. Bangkok: RAP Publication.

Sirajuddin, S.N, Aminawar, M., Amrawaty, A., \& Nurlaelah, S.. (2015). The application of Tesang sharing system at cattle farm in Indonesia. Proceedings of the 3rd International Seminar on Animal Industry, Bogor, 17-18 September 2015. Bogor: Faculty of Animal Science Bogor Agricultural University. 
Suprapto, A. (2002). Land and water resources development in Indonesia. In Investment in Land and Water (Proceedings of the Regional Consultation), by Food and Agriculture Organization of the United Nations. Bangkok: RAP Publication.

Smith, S., Windmeijer, F., \& Wright, E. (2014). Peer Effects in Charitable Giving: Evidence from the (Running) Field. The Economic Journal 125 (35), 1053-1071. DOI: $\underline{10.1111 / \text { ecoj.12114 }}$

Thaker, M.A.M. \& Thaker, H.M.T (2018). SMEs financing and the potential of crowdfunding. Working paper

The World Bank. (2017). Indonesia GDP Share of Agriculture.

Zhang, Juanjuan, \& Liu, P. (2012). Rational herding in microloan markets. Management Science, 58(3), 892-912. DOI: $\underline{10.2307 / 41499528}$

Zyl, J. Van, H.J.G. Nel, \& J. A. Groenewald. (1988). Agriculture's contribution to the South African economy. Agricultural Economics Research, Policy and Practice in Southern Africa, 27(2), 1-9. DOI: $10.1080 / 03031853.1988 .9524124$ 